Global Conferences Series:

Social Sciences, Education and Humanities (GCSSSEH), Volume 3, 2019

The $1^{\text {st }}$ International Conference on Education, Social Sciences and Humanities

DOI: https://doi.org/10.326/hum0217

\title{
Improvement of Learning Office Administration Education Students with the Use of Authentic Assessment Performance in Office Practice
}

\author{
Madziatul Churiyah ${ }^{1}$, Taspin Agustina Puspa ${ }^{2}$, Agung Winarno', \\ Buyung Adi Dharma ${ }^{4}$, Andi Basuki ${ }^{5}$ \\ 1,2,3,4,5 Universitas Negeri Malang Indonesia \\ madziatul.churiyah.fe@um.ac.id
}

\begin{abstract}
The purpose of this research and development is to produce an authentic performance-based assessment instrument for Office Practice courses for student Bachelor of Office Administration EducationThe assessment instrument developed includes unique psychomotor aspects to identify various skills that should have by students. This research was used by the Research and Development model of the Borg and Gall model. Product development results are validated by experts of content and construction. The trial of the assessment instrument was conducted to the 31 Office Administration Education students at Universitas Negeri Malang. The results of the study show that this authentic assessment can improve student competency in accordance with the challenges of the 21st century because the task given replicates real-world challenges and performance standards that are usually carried out by experts or professionals in the field. Lecturers can measure the effectiveness of intellectual achievement or the ability of students to understand and think of high-level students.
\end{abstract}

Keywords: authentic assessment, psychomotor aspects, office practice

\section{Introduction}

Higher education as the highest educational institution in Indonesia has a significant contribution in producing graduates who are competent and have high usefulness in the community. One standard of learning assessment must include the principle of authentic assessment. This authentic assessment can serve as a powerful tool for assessing 21st century student competence in the context of global education reform, because the tasks given replicate real-world challenges and performance standards that are usually carried out by experts or professionals in the field, in addition through assessment authentic lecturers can measure the effectiveness of intellectual achievement or ability of students in problem-solving, high-level thinking to complete assignments (Koh, 2017). Authentic assessment, students have the opportunity to synthesize knowledge and learning processes, to create new strategies or products by focusing on the assessment of continuous learning processes and learning outcomes that reflect students' abilities

Copyright (c) 2019, the Authors. Published by Redwhite Press.

Page | 198 This is an open access article under the CC BY-NC license (http://creativecommons.org/licenses/by-nc/4.0). 
(Webb, 2010). This authentic assessment collaborates between the knowledge, skills and learning processes that are relevant to completing a given task (Hassanpour et al., 2010). Tasks given to students have a correlation and relevance to the real world, able to be applied in the lives of students outside the classroom office practicum subjects so that students know the benefits of the assignments and the assessment carried out (Kearney and Parkins, 2014). Another idea was conveyed (Majid 2014) that authentic assessment can provide a clear picture of how far students are able to master the material and be able to apply it in the learning process.

Authentic assessment is very close to the real activities of students, through giving assignments such as Student Worksheets to be observed with performance observation sheets and performance assessment criteria (Syaifuddin, 2015). The Student Worksheet developed later requires students to be active in giving responses, skilled in applying their knowledge and expertise in working on practical assignments and student learning outcomes which are descriptions of processes and results of performance practices during learning (Cotrus \& Stanciu, 2014). Another opinion was also stated by (Gulikers, et al., 2008: 3) that authentic assessment makes it possible to obtain the quality and authenticity of an assessment. Thus, authentic assessment can be interpreted as a form of assessment that requires students to display performance in real terms as a form of application of knowledge and skills possessed.

Authentic assessments are used to assess competencies that require students to carry out performance or psychomotor performance tasks such as presentations and other practices (Pardimin, 2018). That idea was also supported by (Palm, 2008) which states that performance appraisal is more in line with instruction-oriented tasks that are complemented by guidelines for work procedures and ongoing learning processes. As stated by (Arhin, 2015) that performance appraisal is a type of assessment that requires students to show what they have or what skills they have mastered by doing an activity that they can do.

The assessment instruments that will be developed by researchers are Office Practice subjects that must be taken by 6th-semester students of Office Administration Education Study Programs. In this assessment instrument will be focused on student skills in practicing various office tasks including: (1) management of incoming and outgoing mail and file arrangement / storage based on the development of information technology, (2) procurement of goods, petty cash funds and financial reports, (3) petty cash fund of official business travel and manager's duties, (4) Manage the agenda of the leadership and business travel management, (5) managing the meeting and make note, and (6) office service steps and business communication.

This course is an implementation of various theories about office administration with the aim that students of Office Administration Education Study Program are able to understand and practice various office administration tasks both in the learning process and the world of work in the future. The results of the preliminary study show that there has not been an authentic assessment of the office practice courses arranged in detail and valid in the form of observation sheets and assessment criteria used, the assessment is given to students still refers to the results of assignments collected by students. Kinay \& Bagceci (2008) describes performance assessment represented as a direct assessment that contains techniques such as teacher observation, group projects, tests and non-tests. Also, according to the practice activities carried out also in accordance with performance appraisals, Marhaeni (2009) states that the main component of the task is the performance 
assessment, namely performance tasks, rubrics, and assessment methods. So that the assessment that has been done in Office Practice subjects, is not authentic in assessing student skills. To adapt to these problems, it is necessary to develop authentic assessment instruments to assess student skills in carrying out authentic office practice tasks. $\backslash \backslash$

\section{Method}

This study uses the modified Research \& Development (R \& D) model of Borg \& Gall (1983). The Research and Development Procedure (R \& D) is arranged in 5 steps in Figure 1 below:

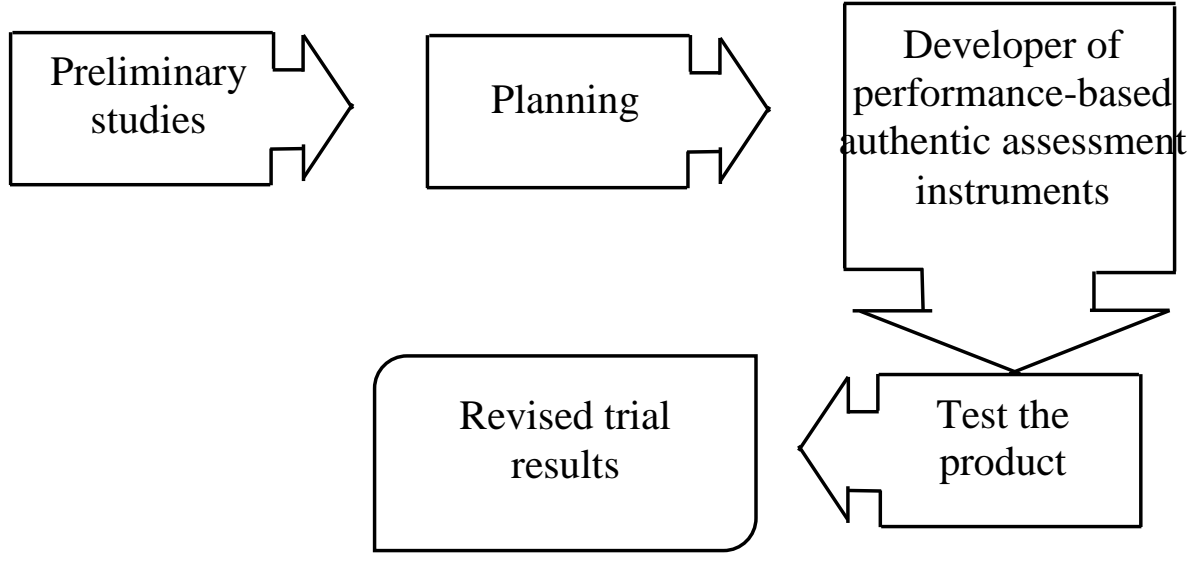

Figure1. Research Steps Development of Performance-Based Authentic Assessment Instruments in Office Practice Courses.

The limited trial subjects in this study were 4 lecturers and 31 students of Office Administration Education, Faculty of Economics, Universitas Negeri Malang. There are 3 types of questionnaires used, namely validation questionnaires, response questionnaires, Office Administration Education lecturers and student response questionnaires to Student Worksheets whose indicators are presented in Table 1.

Table 1. Research Instruments

\begin{tabular}{ll}
\hline Instrument & \multicolumn{1}{c}{ Indicator } \\
\hline Validation of Content & Instruments appropriate with learning outcomes \\
\cline { 2 - 2 } & $\begin{array}{l}\text { Aspects that measured appropriate with the } \\
\text { learning objectives }\end{array}$ \\
\cline { 2 - 2 } Clarity of instructions and indicators \\
\cline { 2 - 2 } Step systematic work \\
\cline { 2 - 2 } Selection of the right sentence \\
\cline { 2 - 2 } Scoring clarity \\
\hline Validation of Construct & $\begin{array}{l}\text { Task performance directs the achievement of } \\
\text { learning outcomes }\end{array}$ \\
\hline
\end{tabular}




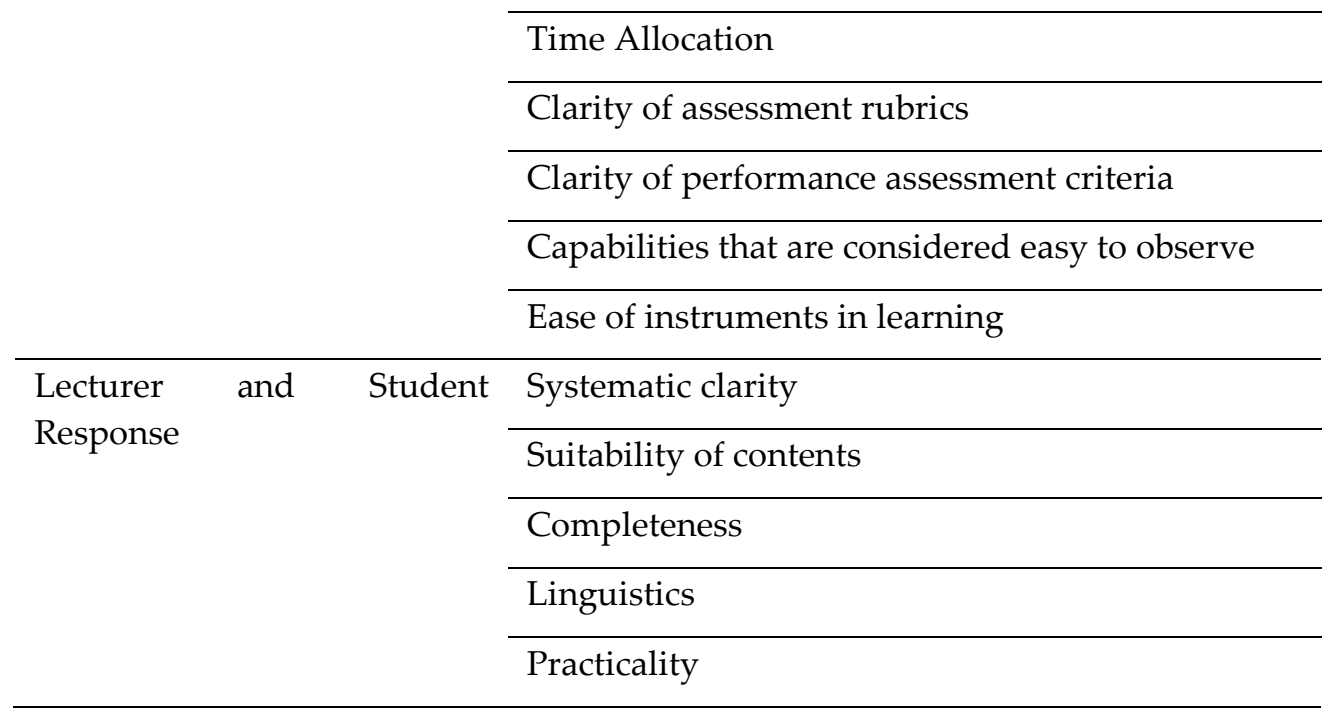

Data analysis techniques using the following formula:

$$
\begin{aligned}
& \text { Tse } \\
& \mathrm{P}=\longrightarrow \times 100 \% \\
& \text { Tsh } \\
& \text { Explanation: } \mathrm{P}=\text { persentase } \\
& \text { Tse }=\text { empirical score } \\
& \mathrm{Tsh}=\text { expected score }
\end{aligned}
$$

The expected level of the feasibility of the product from the development research is identified by the percentage score. The greater the score of the results of data analysis, the better the level of product feasibility.

\section{Results and Discussion}

The development of this performance-based authentic assessment instrument produced five products that showed in Table 1:

Table 1. Product Description Development of Performance-Based Authentic Assessment

\begin{tabular}{l}
$\begin{array}{c}\text { Tool for } \\
\text { performance- } \\
\text { based } \\
\text { authentic } \\
\text { assessment } \\
\text { instruments }\end{array}$ \\
\hline Guideline for Containing product descriptions and how to use products that \\
Using the function makes it easier for lecturers and students to use authentic \\
Psychomotor performance-based assessment instruments. \\
Assessment \\
Instrument \\
\hline Guideline for Contains the provisions of the value or processing of task \\
\hline
\end{tabular}




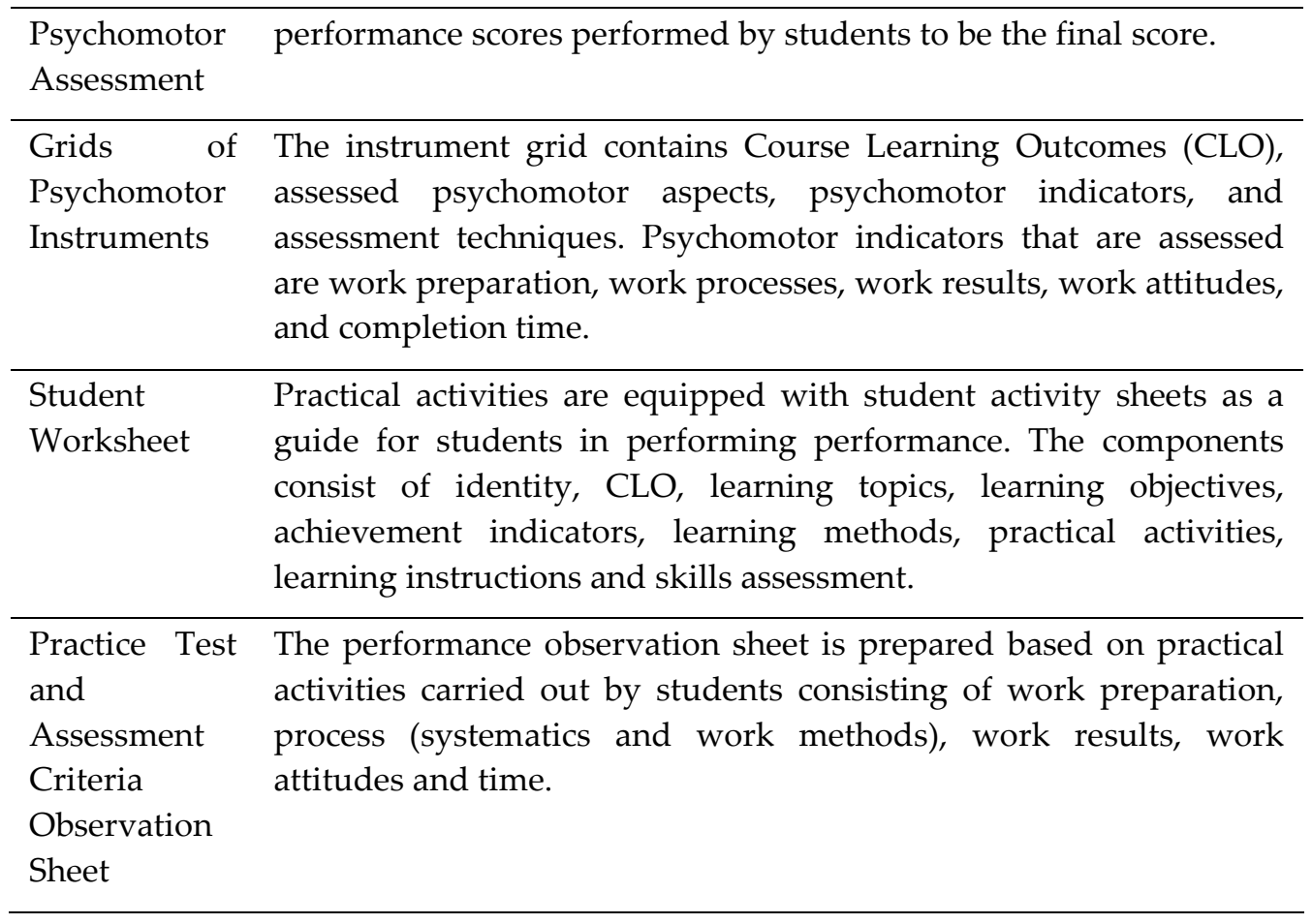

The development of a performance-based authentic assessment instrument was validated by the content and construct validator. The results of the validation show that the Performance-Based Authentic Assessment Instrument for psychomotor aspects obtained an average of $92 \%$.

The results of data analysis in the trial were limited to the 4 lecturers and 31 students show in Table 2

Table 2 Test Results on Student Worksheets and Performance-based Authentic Assessments

\begin{tabular}{lcc}
\hline \multicolumn{1}{c}{ Subject } & $\mathbf{( \% ) \text { Empirical score average }}$ & Validation Criteria \\
\hline Lecturer & 94 & Very good \\
\hline Student & 92 & Very good \\
\hline
\end{tabular}

This authentic assessment instrument was developed based on Minister of Technology Research and Higher Education Regulation No. 44 of 2015 concerning the National Standards for Higher Education which included standards of assessment of learning by including authentic principles. Koh (2017) that this authentic assessment can serve as a powerful tool for assessing 21st century student competence in the context of global education reform, because the tasks assigned replicate real-world performance challenges and standards that are usually carried out by experts or professionals in the field (Chong, et al., 2016), in addition through authentic assessment, lecturers can measure the effectiveness of intellectual achievement or the ability of students to demonstrate understanding, think high-level (Keinanen, et al., 2018), and solve complex problems through performance in completing tasks which is given. This authentic assessment of students has the opportunity to synthesize knowledge and processes, to create new strategies or products, which in the assessment are oriented towards a 
continuous learning process and learning outcomes that reflect the ability of students (Webb, 2010). The idea is reinforced by Pardimin (2018), where authentic assessment provides a description of the task to students in the form of problem-solving questions that demand students' knowledge and skills. Another statement was stated by Yusof, et al. (2012) that in authentic assessment, student performance is measured based on several aspects, including: emphasizing students can apply knowledge based on what students know, focusing on whether students can achieve learning goals, using a variety of realistic problems so students can get to know their work experience, and support students' open thinking in doing the assignments given. Basically, this authentic assessment focuses students to collaborate between knowledge, skills and learning processes that are relevant to solving problems or assignments given by lecturers (Hassanpour et al., 2011). This performance-based authentic assessment instrument can provide a real assessment (Syaifuddin, 2015), which means that authentic assessment is very close to the students' real activities, through assignments in the form of Student Worksheets which can then be observed with performance observation sheets and performance assessment criteria, so that the assessment given according to the results of student work. The Student Worksheet developed later requires students to be active in giving responses, skilled in applying their knowledge and expertise in working on practical assignments and student learning outcomes which are descriptions of processes and results of performance practices during learning (Cotrus \& Stanciu, 2014). Tasks given to students have a correlation and relevance to the real world, able to be applied in the lives of students outside the classroom office practice subjects so that students know the benefits of the assignments and the assessment carried out (Kearney and Parkins, 2014). Authentic assessment makes it possible to obtain the quality and authenticity of an assessment (Gulikers et al., 2008). Therefore, the existence of an authentic assessment will help the lecturer to know how far the student's ability to follow the learning process.

Performance assessments instruments for psychomotor aspects developed by researchers are in accordance with the instrument proposed by Pardimin (2018) that authentic assessments are used to assess achievement competencies which require students to perform psychomotor domains/tasks, such as presentations, correspondence and filing practices. The idea was also supported by Palm (2008) which states that performance appraisal is more in line with instructional tasks equipped with guidelines for work procedures and learning to obtain and measure attitudes, knowledge, abilities and competencies that students have and will later be needed in society. The instrument used can be a rating scale and assessment rubric as a guide in making observations. The use of the rubric in performance appraisal provides effectiveness in determining the path for lecturers and students to find and obtain results that are appropriate to the learning objectives (Damayanti et al., 2017). Practical activities carried out are also in accordance with performance assessment, according to Marhaeni (2009) which states that the main component of the task is performance appraisal, namely performance tasks, rubrics, and assessment methods. Another idea was added by Kinay \& Bagceci (2016) that authentic assessment is also represented as performance assessment, appropriate assessment, alternative assessment, or direct assessment, which contains techniques such as written tests, portfolios, and teacher observations, and group projects.

\section{Conclusions}

The conclusion in this research is that this research and development produces an authentic performance-based assessment instrument in Office Practice Subjects. The assessment instrument developed was a psychomotor assessment instrument with all 
aspects validated by the content expert, constructor expert validation, and tested on lecturers and students.

This authentic assessment must be carried out carefully and thoroughly by the lecturer, meaning that in carrying out an authentic assessment of performance observations or practice implementation, the lecturer must focus on the assessment criteria that appear to students when implementing the process starting from preparation, work process, results, attitude to timeliness and not only see the final results of student assignments.

\section{References}

Arhin, A. K. (2015). The Effect of Performance Assessment-Driven Instruction on the Attitude and Achievement of Senior High School Students in Mathematics in Cape Coast Metropolis Ghana. Journal of Education and Practice, 6 (2), 109-116. www.iiste.org.

Borg, W, R., \& Gall, M, D. (1983). Educational Research an Introduction (Fourth Edition). New York, London: Longman Inc.

Chong, E.J.M., Lim, J.S.W., Liu, Y., Lau, Y.Y.L.L., Wu, V.X. 2016. Improvement of Learning Domains of Nursing Students With the Use of Authentic Assessment Pedagogy in Clinical Practice. Nurse Education in Practice. 20, 125-130.

Cotrus, A. \& Stanciu, C. (2014). A Study on Dynamic Assessment Techniques, as a method of obtaining a high level of learning potential, untapped by conventional assessment. Procedia-Social and Behavior Sciences. 116: 2616-2619.

Gulikers, J. T. M., Bastiaens, Th. J., \& Kirschner, P. A. (2008). Authentic assessment, student and teacher perceptions: the practical value of the five dimensionalframework. Journal of Vocational Education and Training, 58, 337-357.

Hassanpour, B., Utaberta, N., Abdullah, N., Spalie, \& Tahir, M. (2011). Authentic Assessments or Standardized Assessment New Attitude to Architecture Assessment. Procedia Social and Behavioral Sciences. 15(2011). 3550-3595.

Kearney, S. P., \& Perkins, T. (2014). Engaging Students through Assessment: The Success and Limitations of the ASPAL (Authentic Self and Peer Assessment for Learning) Model. Journal of University Teaching \& Learning Practice, 11(3), 2014.

Keinanen, M., Ursin, J., Nissinen, K. (2018). How to Measure Students' Innovation Competencies in Higher Education: Evaluation of an Assessment Tool in Authentic Learning Environments. Studies in Educational Evaluation.Volume 58, September, 30-36.

Kinay, I. \& Baggceci, B. (2016). The Investigation of the Effects of Authentic Assessment Approach on Prospective Teachers' Problem-Solving Skills. International Education Studies. 9(8), 51-59.

Koh, K. H. (2017). Authentic Assessment. Oxford Research Encyclopedia of Education. 1-24.

Majid, A. 2014. Penilaian autentik proses dan hasil belajar. Bandung: Interest.

Marhaeni, A.A.I.N., Ramendra, D. P. \& Dewi, E. S. (2012). Pelatihan Pengembangan Penilaian Kinerja Menulis Bahasa Inggris Bagi Guru Bahasa Inggris Sma Kecamatan Buleleng. Laporan Pengabdian Masyarakat tidak diterbitkan. Singaraja: UPG Fakultas Bahasa \& Seni.

Minister of Technology Research and Higher Education Regulation No. 44 of 2015 concerning National Standards for Higher Education. Kopertis (online), (kopertis3.or.id/v2/wp.../Bu-Illah-SN-DIKTI-44-2015-SOSIALISASI-APTISI.pdf). 
Palm, T. (2008). Performance Assessment and Authentic Assessment: A Conceptual Analysis of the Literature. Practical Assessment Research and Evaluation A PeerReviewed Electronic Journal. 13(4). 1-11.

Pardimin. (2018). Analysis of the Indonesia Mathematics Teachers' Ability in Applying Authentic Assessment. Cakrawala Pendidikan, 2(2018), 170-181.

Syaifuddin, M. (2015). Students Performance of Statistics in Stad Model and Authentic Assessment. Advances in Environmental Biology Journal. 9 (24).

Webb, D. C. (2010). Troubleshooting Assessment: An Authentic Problem Solving Activity For It Education. Procedia-Social and Behavior Science, 9(2010), 903-907.

Yusof, N., Amin, M.M., Arshad, M., Dahlan, H.M., \& Mustafa, N. (2012) Authentic Assessment of Industrial Training Program: Experience of Universiti Teknologi Malaysia 56. Procedia - Social and Behavior Sciences, 56, 724-729. 